\title{
Comparison of Molecular Methods for the Detection of Eimeria in Domestic Chickens in Malaysia
}

(Perbandingan Kaedah Molekul untuk Pengenalpastian Eimeria dalam Ayam Ternakan di Malaysia)

\author{
SHU-SAN LOO, LIK-Sin LIM, NURUL-Ain EFENDI, DAMER P. BlAKE, SHIN-ICHIRo KAWAZU \& KIEW-LiAN WAN*
}

\begin{abstract}
Coccidiosis, caused by the Eimeria species, greatly affects the poultry industry. Severity of the disease varies depending on the identity of the infecting parasites, encouraging identification of Eimeria species circulating on a farm as a valuable component of chicken management. Conventional methods of Eimeria species identification are time consuming and can be subjective in nature. Given these limitations, molecular approaches have been developed for specific detection of Eimeria species. In this study, faecal samples were collected from commercial broiler farms and subjected to microscopic examination for Eimeria occurrence. Eimeria species were putatively identified by morphological characterisation and grouped into three categories based on oocyst size. Molecular detection of Eimeria species occurrence in these samples was then performed using two published PCR assays (the individual components of a SCAR-based multiplex PCR, and assays developed for quantitative PCR, termed PCR-SCAR 1 and PCR-SCAR 2 here) and a LAMP assay. Comparison of the results obtained demonstrated that the three molecular methods were capable of detecting all Eimeria species of the reference Houghton strain, but showed varying efficiencies in detecting Malaysian field isolates. PCR-SCAR 2 was found to be the most effective, detecting all seven Eimeria species and indicating the presence of Eimeria parasites in most flocks. Differences in the ability of the molecular methods to detect Eimeria may be a consequence of sequence divergence between isolates from different regions, implying that development of region-specific methods using local Eimeria strains may be required to improve the efficiency of molecular assays for Eimeria detection.
\end{abstract}

Keywords: Coccidiosis; LAMP; protozoan parasite; SCAR

\section{ABSTRAK}

Koksidiosis yang disebabkan oleh spesies Eimeria, memberikan kesan yang besar terhadap industri penternakan ayam. Keparahan penyakit ini bergantung kepada identiti parasit yang menjangkit dan ini menggalakkan usaha pengenalpastian spesies Eimeria yang hadir dalam ladang ayam sebagai komponen yang penting dalam pengurusan ayam. Kaedah konvensional pengenalpastian spesies Eimeria memakan masa dan didapati bersifat subjektif. Disebabkan oleh kekangan kaedah ini, pendekatan molekul telah dibangunkan untuk pengenalpastian spesies Eimeria secara spesifik. Dalam kajian ini, sampel tinja telah dikumpul dari ladang ayam pedaging komersial dan disaring melalui pemerhatian mikroskop untuk mengesan kehadiran Eimeria. Spesies Eimeria telah dikenal pasti secara pencirian morfologi dan dikelompokkan kepada tiga kategori berdasarkan saiz oosista. Pengesanan molekul terhadap kehadiran spesies Eimeria dalam sampel tersebut kemudiannya telah dilakukan dengan menggunakan dua asai PCR yang telah diterbitkan (komponen individu PCR multipleks berasaskan SCAR, dan asai yang dibangunkan untuk PCR kuantitatif yang dikenali sebagai PCR-SCAR 1 dan PCR-SCAR 2) dan asai LAMP. Perbandingan hasil yang diperoleh menunjukkan bahawa ketiga-tiga kaedah molekul ini mampu mengesan kesemua spesies Eimeria daripada strain rujukan Houghton, tetapi menunjukkan kecekapan yang berbeza dalam mengesan pencilan lapangan dari Malaysia. PCR-SCAR 2 didapati paling berkesan dan berupaya mengesan kesemua tujuh spesies Eimeria serta menunjukkan kehadiran parasit Eimeria dalam kebanyakan populasi ayam. Perbezaan dalam keupayaan kaedah molekul untuk mengesan Eimeria mungkin disebabkan oleh perbezaan jujukan antara pencilan dari kawasan yang berbeza, dan ini mencadangkan bahawa pembangunan kaedah berasaskan kawasan yang khusus menggunakan strain Eimeria tempatan adalah diperlukan untuk meningkatkan kecekapan asai molekul untuk pengesanan Eimeria.

Kata kunci: Koksidiosis; LAMP; parasit protozoa; SCAR

\section{INTRODUCTION}

Coccidiosis is an enteric disease that causes significant losses to the livestock production industry by reducing animal performance and lowering productivity. Parasites of the protozoan Eimeria species are known to be causative agents of avian coccidiosis, a disease that threatens almost all of the $\sim 60$ billion chickens reared worldwide annually (Blake \& Tomley 2014). Control of the disease is mainly achieved through prophylactic chemotherapy, supplemented by vaccination. However, 
these control methods have their disadvantages. The emergence of drug-resistant strains due to persistent use of anticoccidial drugs complicates their application (Chapman 1997). Live parasite vaccines are becoming increasingly popular in some regions (Chapman \& Jeffers 2014), but uptake remains limited by production costs and capacity. Identification of Eimeria species that are present in chicken flocks can improve management of the disease, and aid in the development of more efficient control methods.

Conventionally, detection and identification of Eimeria species have been based on comparing clinical features, gut pathology in the host, morphology of sporulated oocysts and/or pre-patent period (Long et al. 1976). Such methods remain widely used, although their subjective nature, low throughput and requirement for trained specialists can prove limiting. Problems in the precise discrimination of species with overlapping morphological characteristics can arise when dealing with mixed populations (Long \& Joyner 1984). In response, several molecular approaches have been developed to improve Eimeria species identification, including polymerase chain reaction (PCR) assays based on 5S rRNA (Stucki et al. 1993), small subunit rRNA (Tsuji et al. 1997), internal transcribed spacer-1 (ITS1) (Lew et al. 2003; Schnitzler et al. 1998, 1999; Su et al. 2003), ITS-2 (Gasser et al. 2001; Lien et al. 2007) and Sequence Characterised Amplified Region (SCAR) markers (Fernandez et al. 2003a, 2003b). In addition, other molecular methods such as quantitative PCR (Morgan et al. 2009; Vrba et al. 2010) and Loop-Mediated Isothermal Amplification (LAMP) (Barkway et al. 2011) have also been introduced.

In this study, two PCR assays were employed to detect Eimeria species circulating in Malaysian broiler chicken farms. The first PCR assay utilised primers targeting SCAR markers as described by Fernandez et al. (2003a, 2003b), while the second assay was performed using primers originally developed for quantitative PCR that target unique single copy sequences derived from SCAR markers as described by Vrba et al. (2010). In addition, a LAMP assay described by Barkway et al. (2011) was performed for comparison. The detection of Eimeria species parasites using molecular methods can aid farmers and relevant authorities in the management of avian coccidiosis, and contribute towards the development of more efficient control strategies.

\section{MATERIALS AND METHODS}

SAMPLE COLLECTION AND MORPHOLOGICAL IDENTIFICATION

A total of 18 samples were collected from commercial broiler farms located in Peninsular Malaysia (Figure 1). Faecal samples of $\sim 45 \mathrm{~g}$ were collected from the floor of each chicken pen when the birds were between three and four weeks old. Samples were enriched by flotation in saturated saline solution to separate oocysts from faecal debris (Shirley 1995). All samples were inspected microscopically to confirm the presence of Eimeria oocysts. The purified oocysts were then sporulated in $2 \%$ $(\mathrm{w} / \mathrm{v})$ potassium dichromate. Total number of oocysts was determined by enumeration using the Fuchs-Rosenthal haemocytometer counting method (Shirley et al. 2005). Subsequently, oocysts were assigned putative species identity based on microscopic morphology (Long et al. 1976), assigning oocysts to species groups based on oocyst size (Haug et al. 2008). The reference Houghton strains of each Eimeria species were used as positive controls.

\section{ISOLATION OF GENOMIC DNA}

Genomic DNA was isolated based on the protocol previously described by Fernandez et al. (2003a) with minor modifications. Purified oocysts were suspended in extraction buffer $(10 \mathrm{mM}$ Tris- $\mathrm{HCl}, \mathrm{pH} 8.0 ; 50 \mathrm{mM}$ EDTA, pH8.0) and an equal volume of glass beads (0.5 $\mathrm{mm}$ diameter) was added. The mixture was homogenised using a bead beater for one min followed by centrifugation at $\sim 750 \mathrm{~g}$ for $10 \mathrm{~min}$. The supernatant was treated with proteinase $\mathrm{K}(100 \mu \mathrm{g} / \mathrm{mL})$ and $\operatorname{SDS}(0.5 \%)$ for $2 \mathrm{~h}$ at $55^{\circ} \mathrm{C}$. The genomic DNA was isolated using phenol/ chloroform extraction followed by ethanol precipitation and dissolution in deionised water.

\section{PCR-SCAR 1 ASSAY}

PCR-SCAR 1 assays were performed as described by Fernandez et al. (2003a) using primers with a diagnostic sensitivity of 1-5 pg genomic DNA, equivalent to between two and eight sporulated oocysts, as reported in Fernandez et al. (2003b). The species-specific assays for all seven Eimeria species were performed separately. Briefly, amplification was carried out in $25 \mu \mathrm{L}$ reaction volumes containing $2 \mu \mathrm{L}$ of sample DNA, $1 \mu \mathrm{M}$ of each pair of SCAR primers, $0.2 \mathrm{mM}$ of dNTPs, $1.5 \mathrm{mM}$ of $\mathrm{MgCl}_{2}, 1 \times$ reaction buffer and $1 \mathrm{U}$ of Taq DNA polymerase (New England Biolabs). Cycling conditions comprised of an initial denaturation step at $94^{\circ} \mathrm{C}$ for 3 min followed by 30 cycles of $1 \mathrm{~min}$ at $94^{\circ} \mathrm{C}, 30 \mathrm{~s}$ at $62^{\circ} \mathrm{C}$ and $1.5 \mathrm{~min}$ at $72^{\circ} \mathrm{C}$, with a final extension step at $72^{\circ} \mathrm{C}$ for $7 \mathrm{~min}$. PCR products were visualised by electrophoresis on $1.8 \%(\mathrm{w} / \mathrm{v})$ agarose gels stained with ethidium bromide.

\section{PCR-SCAR 2 ASSAY}

PCR-SCAR 2 assays were performed using primers with a diagnostic sensitivity of approximately ten copies, equivalent to between one and two sporulated oocysts, as reported by Vrba et al. (2010). The assays were performed in $20 \mu \mathrm{L}$ reaction volumes containing $2 \mu \mathrm{L}$ of sample DNA, $0.5 \mu \mathrm{M}$ of each forward and reverse primers, $0.2 \mathrm{mM}$ of dNTPs, $1.5 \mathrm{mM}$ of $\mathrm{MgCl}_{2}, 1 \times$ reaction buffer and $0.5 \mathrm{U}$ of Taq DNA polymerase (New England Biolabs). Cycling conditions comprised of an initial denaturation step at $95^{\circ} \mathrm{C}$ for $1 \mathrm{~min}$ followed by 35 cycles at $95^{\circ} \mathrm{C}$ for $15 \mathrm{~s}$ and $60^{\circ} \mathrm{C}$ for $30 \mathrm{~s}$. PCR products were visualised by electrophoresis on $1.8 \%(\mathrm{w} / \mathrm{v})$ agarose gels stained with ethidium bromide. 


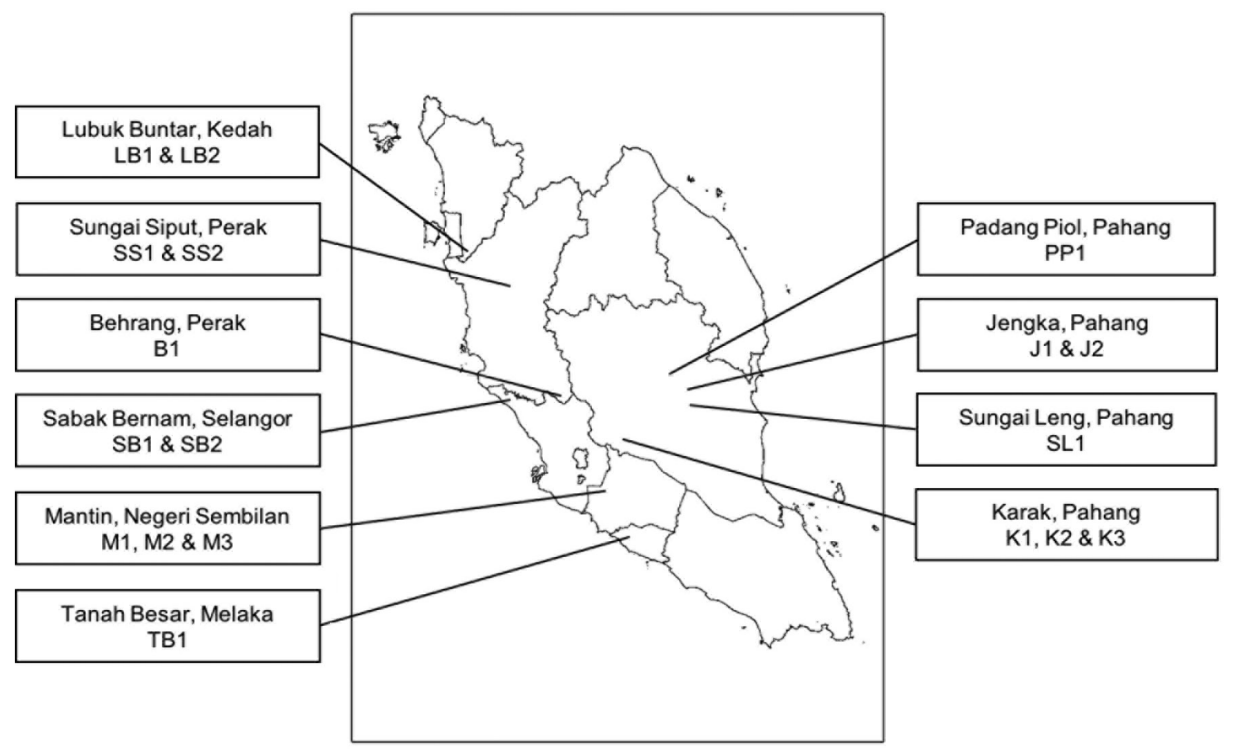

FIGURE 1. Geographical distribution of broiler chicken farms sampled during these studies across six states in Peninsular Malaysia

\section{LAMP ASSAY}

LAMP assays were performed as described by Barkway et al. (2011) in a final volume of $25 \mu \mathrm{L}$ containing $8 \mathrm{U}$ of Bst DNA polymerase (large fragment; New England Biolabs) in $1 \times$ ThermoPol Reaction buffer (New England Biolabs) supplemented with $2 \mathrm{mM}$ of $\mathrm{MgCl}_{2}, 1 \mathrm{M}$ of betaine and 0.4 $\mathrm{mM}$ of each dNTP. LAMP oligonucleotides FIP and BIP (40 pmol), LB and LF (20 pmol), and F3 and B3 (5 pmol), were added together with $2 \mu \mathrm{L}$ of sample DNA. Each reaction was incubated at $62^{\circ} \mathrm{C}$ for $30 \mathrm{~min}$ and then $80^{\circ} \mathrm{C}$ for $5 \mathrm{~min}$ to terminate the reaction. LAMP products were visualised by electrophoresis on $1.8 \%(\mathrm{w} / \mathrm{v})$ agarose gels stained with ethidium bromide. The diagnostic sensitivity of the assay has been reported to be approximately ten copies, equivalent to between one and two sporulated oocysts (Barkway et al. 2011).

\section{RESULTS AND DISCUSSION}

To provide baseline data, Eimeria oocysts present in all 18 samples were assigned putative species identity based upon microscopic morphological characterisation. The samples were assigned into three categories; the small oocysts were categorised as E. acervulina or E. mitis (group AM, $\leq 18.8 \mu \mathrm{m}$ long), medium sized oocysts as E. necatrix, E. tenella or E. praecox (group NTP, 18.9-23.8 $\mu \mathrm{m}$ long) and the larger oocysts as E. brunetti or E. maxima (group $\mathrm{BM}, \geq 23.9 \mu \mathrm{m}$ long). Small oocysts, representing the AM group, were detected in all 18 samples. Of the 18 samples, 16 were also found to contain medium sized oocysts (NTP group) while 14 samples were found to contain the large sized oocysts (BM group). Previous studies carried out in Czechoslovakia (Kucera 1990), France (Williams et al. 1996) and Korea (Lee et al. 2010) reported E. acervulina to be the most highly prevalent species, while studies in China (Sun et al. 2009), India (Bhaskaran et al. 2010),
Jordan (Al-Natour et al. 2002) and Iran (Hadipour et al. 2013) showed E. tenella to be highly prevalent. These studies conducted in countries from several regions of the world show that both E. acervulina and E. tenella are common among chicken farms, which is consistent with the occurrence of AM and NTP Eimeria species found in the 18 samples.

Subsequently, two PCR assays (PCR-SCAR 1 and PCRSCAR 2) and a LAMP assay were employed for the detection of Eimeria species DNA extracted from the same faecal samples. The three assays could be performed rapidly using a common reaction temperature for all seven Eimeria species, whereas other assays such as those based on ITS1 required independent annealing temperatures for each Eimeria species. Therefore, the three assays were chosen based on their practicality as diagnostics methods. The specificity of all three assays has been demonstrated, amplifying only from target Eimeria species with no crossreactivity to other species or the chicken host (Fernandez et al. 2003b; Vrba et al. 2010; Barkway et al. 2011).

The PCR-SCAR 1 assay utilised primers that target species-specific SCAR markers derived from random amplification of polymorphic DNA (RAPD) fragments. During validation, the primers were tested using isolates of all seven Eimeria species collected from three geographical regions, namely South America, North America and Europe. More recently the assay has also been tested using isolates collected in Asia (India; Kumar et al. 2014). When PCR-SCAR 1 assays were carried out for the field samples, Eimeria species were found to be present in 11 out of $18(61 \%)$ broiler farms. Six species comprising $E$. acervulina, E.tenella, E. mitis, E. praecox, E. maxima and $E$. necatrix were identified. The most prevalent species was E. acervulina (44\%), followed by E. tenella, E. praecox and E. maxima (all 22\%). Eimeria mitis and $E$. necatrix were found in only one farm, respectively, while 
E. brunetti was not detected in any of the 18 farms that were sampled (Table 1). Out of the 11 farms that were found to be infected by molecular analysis, seven farms $(64 \%)$ were detected with only one species, while mixed infections with two or more species were found in four farms (36\%). Geographical distribution indicated that $E$. acervulina was prevalent in all six states in Peninsular Malaysia while E. tenella was present in Selangor and Pahang. Both E. praecox and E. maxima were detected in Selangor, Pahang and Negeri Sembilan, while E. mitis was detected in Selangor and E. necatrix in Pahang.

The second assay, PCR-SCAR 2, was performed using primers for each of the seven Eimeria species targeting unique single copy sequences derived from SCAR markers as described by Vrba et al. (2010). These markers were previously found to be non-polymorphic following sequencing from multiple strains of each species and appear to be present as single copies per genome. Marker polymorphism and species specificity were assessed using isolates from four geographical regions, namely South America, North America, Europe and Africa, supplemented more recently by samples from Asia (Kumar et al. 2014). When PCR-SCAR 2 assays were carried out for the field samples, Eimeria species were found to be present in 16 out of $18(89 \%)$ broiler farms. All seven species comprising E. acervulina, E. brunetti, E.tenella, E. mitis, E. praecox, $E$. maxima and E. necatrix were identified. The most prevalent species identified was E. acervulina (89\%), followed by E. tenella (33\%), E. praecox (28\%) and E. mitis (22\%). Both E.maxima and E. brunetti were found in three farms, while E. necatrix was found in only one farm. Out of the 16 farms that were found to be infected, five farms $(31 \%)$ were detected with only one species, while mixed infection with two or more species were found in 11 farms (69\%). Eimeria acervulina was detected in all six states in Peninsular Malaysia, while E.tenella was present in Selangor and Pahang. Both E. praecox and E. maxima were detected in Pahang and Negeri Sembilan, with E. mitis in Selangor, Pahang and Negeri Sembilan; E. brunetti in Kedah, Perak and Pahang, and E. necatrix in Pahang.

The third assay, LAMP has been widely recognised as a cost effective diagnostic tool with excellent reproducibility. Assays targeting well-studied apicomplexan parasites have been described for Cryptosporidium (Karanis et al. 2007), Plasmodium falciparum (Poon et al. 2006) and Toxoplasma gondii (Sotiriadou \& Karanis 2008). LAMP is an isothermal nucleic acid amplification technique that is performed without the series of alternating temperature steps or cycles required for PCR. Typically, four different primers are used to identify six distinct regions on the target locus, which adds to the specificity compared to PCR. The amount of DNA produced in LAMP is also considerably higher than PCR. Thus, detection of successful amplification can be determined through photometry for turbidity caused by an increasing quantity of magnesium pyrophosphate precipitate in solution as a by-product of amplification. Hence, this allows easy visualisation by the naked eye compared to PCR, which requires gel electrophoresis

TABLE 1. Summary of Eimeria species infection in 18 farms located at Kedah, Perak, Selangor, Negeri Sembilan, Melaka and Pahang in Peninsular Malaysia

\begin{tabular}{|c|c|c|c|c|c|c|}
\hline \multirow{2}{*}{$\begin{array}{l}\text { Eimeria } \\
\text { species }\end{array}$} & \multicolumn{2}{|c|}{ PCR-SCAR 1} & \multicolumn{2}{|c|}{ PCR-SCAR 2} & \multicolumn{2}{|c|}{ LAMP } \\
\hline & $\begin{array}{l}\text { Prevalence } \\
\quad(n=18)\end{array}$ & Location & $\begin{array}{l}\text { Prevalence } \\
\quad(n=18)\end{array}$ & Location & $\begin{array}{l}\text { Prevalence } \\
\quad(n=18)\end{array}$ & Location \\
\hline Ac & $8 / 18(44 \%)$ & $\begin{array}{l}\text { KDH (2), PRK (1), } \\
\text { SGR (1), NSN (2), } \\
\text { MLK (1), PHG (1) }\end{array}$ & $16 / 18(89 \%)$ & $\begin{array}{l}\text { KDH (2), PRK (2), } \\
\text { SGR (2), NSN (3), } \\
\text { MLK (1), PHG (6) }\end{array}$ & $12 / 18(67 \%)$ & $\begin{array}{l}\text { KDH (2), PRK (2), } \\
\operatorname{SGR}(2), \operatorname{NSN}(2), \\
\operatorname{MLK}(1), \operatorname{PHG}(3)\end{array}$ \\
\hline Mt & $1 / 18(6 \%)$ & SGR (1) & $4 / 18(22 \%)$ & $\begin{array}{c}\text { PHG (1), SGR (2), } \\
\text { NSN (1) }\end{array}$ & - & - \\
\hline $\mathrm{Nc}$ & $1 / 18(6 \%)$ & PHG (1) & $1 / 18(6 \%)$ & PHG (1) & - & - \\
\hline $\mathrm{Tn}$ & $4 / 18(22 \%)$ & SGR (2), PHG (2) & $6 / 18(33 \%)$ & PHG (4), SGR (2) & - & - \\
\hline $\operatorname{Pr}$ & $4 / 18(22 \%)$ & $\begin{array}{c}\text { SGR (1), NSN (2), } \\
\text { PHG (1) }\end{array}$ & $5 / 18(28 \%)$ & PHG (3), NSN (2) & $3 / 18(17 \%)$ & PHG (1), NSN (2) \\
\hline $\mathrm{Br}$ & - & - & $3 / 18(17 \%)$ & $\begin{array}{c}\text { KDH (1), PRK (1), } \\
\text { PHG (1), }\end{array}$ & - & - \\
\hline $\mathrm{Mx}$ & $4 / 18(22 \%)$ & $\begin{array}{c}\text { SGR (1), NSN (1), } \\
\text { PHG (2) }\end{array}$ & $3 / 18(17 \%)$ & PHG (1), NSN (2) & $2 / 18(11 \%)$ & PRK (1), PHG (1), \\
\hline $\begin{array}{l}\text { Total } \\
\text { samples } \\
\text { with }\end{array}$ & $13 / 18(72 \%)$ & & $16 / 18(89 \%)$ & & $15 / 18(83 \%)$ & \\
\hline $\begin{array}{l}\text { Eimeria } \\
\text { parasites }\end{array}$ & & & & & & \\
\hline
\end{tabular}




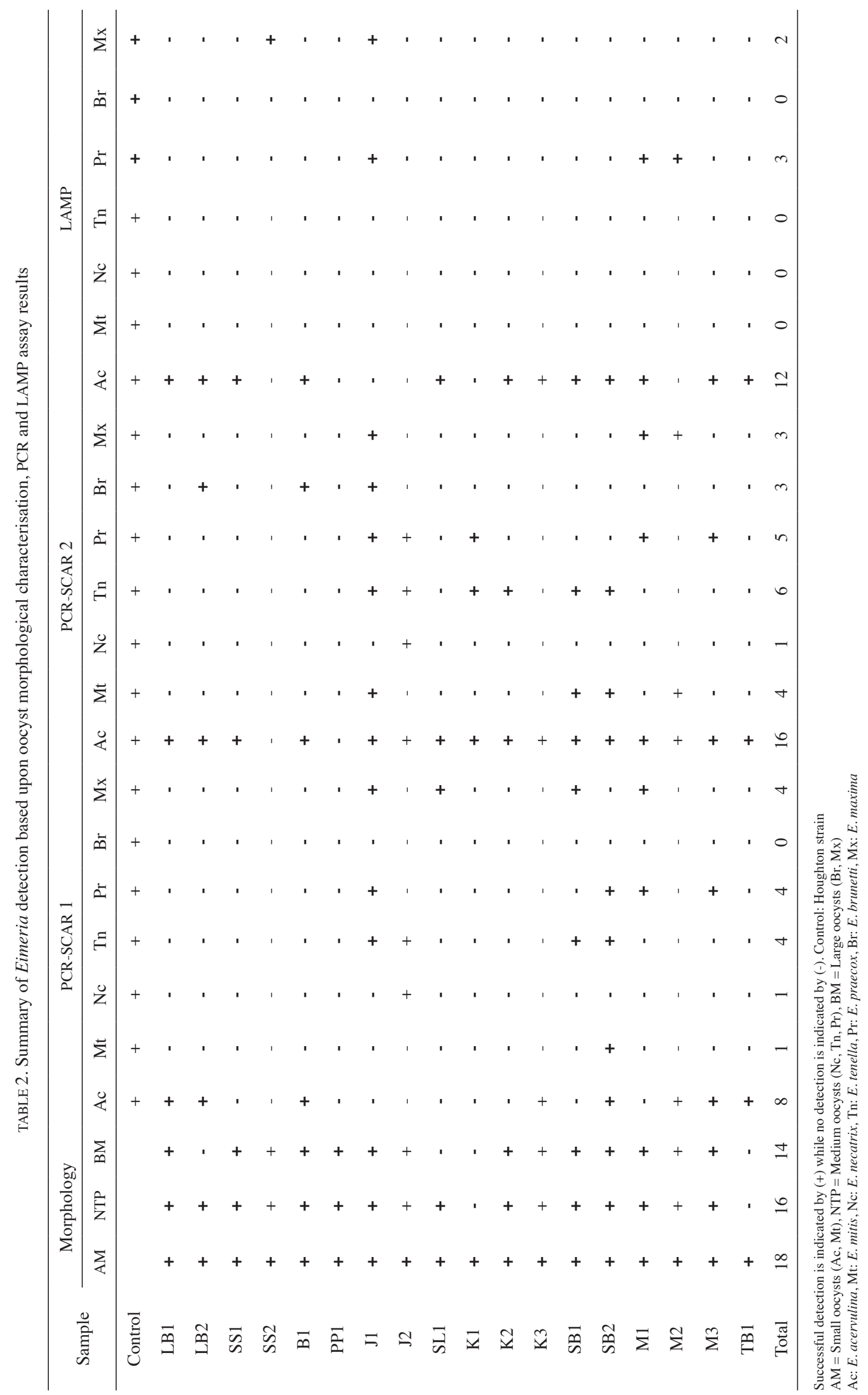


analysis (Notomi et al. 2000). When LAMP assays were carried out for the field samples, Eimeria species were found to be present in 15 out of $18(83 \%)$ broiler farms. Just three species comprising E. acervulina, E. praecox and E. maxima were identified. Overall, the most prevalent species detected was E. acervulina (67\%), followed by $E$. praecox (17\%) and E. maxima (11\%). Eimeria brunetti, E. tenella, E. mitis and E. necatrix were not detected in any of the 18 farms that were sampled. Out of the 15 farms that were found to be infected, 14 farms (93\%) were found to host a single species, while mixed infection with two or more species were found in one farm (7\%). The results of the geographical distribution shown that E. acervulina was also prevalent in all six states in Peninsular Malaysia as detected by PCR-SCAR 1 and PCR-SCAR 2 methods, while E. praecox was present in Pahang and Negeri Sembilan and E. maxima in Perak and Pahang.

The results obtained showed that the three molecular methods were capable of detecting Eimeria species of the reference Houghton strain. Analysis of the field isolates with all three molecular detection methods also demonstrated results comparable with morphological characterisation in that E. acervulina was identified as the most common species. However, these molecular methods showed a high level of variation in detection (Table 2). The PCR-SCAR 2 assay was able to detect all seven Eimeria species, as compared to PCR-SCAR 1 (six species) and LAMP (three species). PCR-SCAR 1 did not detect E. brunetti while four species, namely E. brunetti, E.tenella, E. mitis and $E$. necatrix were not detected by LAMP. Both PCR-SCAR 1 and PCR-SCAR 2 assays were performed using similar reagents with slightly different cycling conditions. The conditions were kept as close as possible to those described in the original publications to permit direct comparison. Thus, the difference in efficiency between the two PCR assays could be due to primer design - PCR-SCAR 2 was developed based on samples from four geographically distant regions (Vrba et al. 2010), while PCR-SCAR 1 was developed based on three geographical regions (Fernandez et al. 2003a, 2003b). A wider geographical coverage could provide higher efficiency in the development of PCR primers to detect local Eimeria populations and multiple infections. The LAMP assay detected fewer species when compared with both PCR assays. This is not surprising since the LAMP assay involves more primers, with a requirement for greater target sequence similarity, which increases the likelihood of it being affected by sequence divergence between strains. Thus, the efficiency differences observed between the LAMP and the two PCR assays in detecting local Eimeria populations may be due, at least in part, to sequence variation in primer annealing sites. The results of this study also suggest that primers from published sources were not able to detect the presence of Eimeria species in all of the samples, despite positive confirmation by microscopic inspection. This is likely due to genetic diversity that is demonstrated by Eimeria species from different geographical regions. Such diversity may have been intra-species specific (i.e. mutations located within primer annealing sites). Alternatively, it may be that oocysts of the cryptic operational taxonomic units (OTUs) $\mathrm{x}, \mathrm{y}$ and/or $\mathrm{z}$ were recovered from these samples (Clark et al. 2016). Recent studies with DNA extracted from Nigerian OTU samples have suggested that molecular diagnostic tools designed to target the seven recognised Eimeria species that infect chickens may not be capable of detecting these cryptic parasites (Jatau et al. 2016).

\section{CONCLUSION}

Current available molecular methods may not be sufficient for the specific detection of local Eimeria species. Primer design at conserved regions of the target gene sequences should include strains from other geographical regions that were not considered in the original studies including Malaysian isolates. Thus, development of methods based on more sensitive primers using local Eimeria strains is required for improved detection of avian coccidiosis in local farms.

\section{ACKNOWLEDGEMENTS}

This work was financially supported by Research University Grants from Universiti Kebangsaan Malaysia (UKM-GUP-2011-186 and ETP-2014-006) and the National Research Center for Protozoan Diseases at Obihiro University of Agriculture and Veterinary Medicine Cooperative Research Grant. The authors would like to thank Prof. Noboru Inoue (National Research Center for Protozoan Diseases, Obihiro University of Agriculture and Veterinary Medicine) for expert advice and critical review of the manuscript.

\section{REFERENCES}

Al-Natoura, M.Q., Suleimana, M.M. \& Abo-Shehadab, M.N. 2002. Flock-level prevalence of Eimeria species among broiler chicks in northern Jordan. Preventive Veterinary Medicine 53: 305-310.

Barkway, C.P., Pocock, R.L., Vrba, V. \& Blake, D.P. 2011. Loopmediated isothermal amplification (LAMP) assays for the species-specific detection of Eimeria that infect chickens. BMC Veterinary Research 7: 67.

Bhaskaran, M.S., Venkatesan, L., Aadimoolam, R., Jayagopal, H.T. \& Sriraman, R. 2010. Sequence diversity of internal transcribed spacer-1 (ITS-1) region of Eimeria infecting chicken and its relevance in species identification from Indian field samples. Parasitology Research 106: 513-521.

Blake, D.P. \& Tomley, F.M. 2014. Securing poultry production from the ever-present Eimeria challenge. Trends in Parasitology 30(1): 12-19.

Chapman, H.D. 1997. Biochemical, genetic and applied aspects of drug resistance in Eimeria parasites of the fowl. Avian Pathology 28: 221-244.

Chapman, H.D. \& Jeffers, T.K. 2014. Vaccination of chickens against coccidiosis ameliorates drug resistance in commercial poultry production. International Journal for Parasitology. Drugs and Drug Resistance 4: 214-217.

Clark, E.L., Macdonald, S.E., Thenmozhi, V., Kundu, K., Garg, R., Kumar, S., Ayoade, S., Fornace, K.M., Jatau, I.D., Moftah, 
A., Nolan, M.J., Sudhakar, N.R., Adebambo, A.O., Lawal, I.A., Zapata, R.A., Awuni, J.A., Chapman, H.D., Karimuribo, E., Mugasa, C.M., Namangala, B., Rushton, J., Suo, X., Thangaraj, K., Rao, A.S.R.S., Tewari, A.K., Banerjee, P.S., Raj, G.D., Raman, M., Tomley, F.M. \& Blake, D.P. 2016. Cryptic Eimeria genotypes are common across the southern but not northern hemisphere. International Journal for Parasitology 46: 537-544.

Fernandez, S., Costa, A.C., Katsuyama, A.M., Madeira, A.M. \& Gruber, A. 2003a. A survey of the inter- and intraspecific RAPD markers of Eimeria spp. of the domestic fowl and the development of reliable diagnostic tools. Parasitology Research 89: 437-445.

Fernandez, S., Pagotto, A.H., Furtado, M.M., Katsuyama, A.M., Madeira, A.M. \& Gruber, A. 2003b. A multiplex PCR assay for the simultaneous detection and discrimination of the seven Eimeria species that infect domestic fowl. Parasitology 127: 317-325.

Gasser, R.B., Woods, W.G., Wood, J.M., Ashdown, L., Richards, G. \& Whithear, K.G. 2001. Automated, fluorescence based approach for the specific diagnosis of chicken coccidiosis. Electrophoresis 22: 3546-3550.

Hadipour, M.M., Olyaie, A., Naderi, M., Azad, F. \& Nekouie, O. 2013. Prevalence of Eimeria species in scavenging native chickens of Shiraz, Iran. African Journal of Poultry Farming 1(2): 34-36.

Haug, A., Gjevre, A.G., Thebo, P., Mattsson, J.G. \& Kaldhusdal, M. 2008. Coccidial infections in commercial broilers: Epidemiological aspects and comparison of Eimeria species identification by morphometric and polymerase chain reaction techniques. Avian Pathology 37(2): 161-70.

Jatau, I.D., Lawal, I.A., Kwaga, J.K.P., Tomley, F.M., Blake, D.P. \& Nok, A.J. 2016. Three operational taxonomic units of Eimeria are common in Nigerian chickens and may undermine effective molecular diagnosis of coccidiosis. $B M C$ Veterinary Research 12: 86.

Karanis, P., Thekisoe, O., Kiouptsi, K., Ongerth, J., Igarashi, I. \& Inoue, N. 2007. Development and preliminary evaluation of a loop-mediated isothermal amplification procedure for sensitive detection of Cryptosporidium oocysts in fecal and water samples. Applied and Environmental Microbiology 73(17): 5660-5662.

Kucera, J. 1990. Identification of Eimeria species in Czechoslovakia. Avian Pathology 19: 59-66.

Kumar, S., Garg, R., Moftah, A., Clark, E.L., Macdonald, S.E., Chaudhry, A.S., Sparagano, O., Banerjee, P.S., Kundu, K., Tomley, F.M. \& Blake, D.P. 2014. An optimised protocol for molecular identification of Eimeria from chickens. Veterinary Parasitology 199: 24-31.

Lee, B.H., Kim, W.H., Jeong, J., Yoo, J., Kwon, Y.K., Jung, B.Y., Kwon, J.H., Lillehoj, H.S. \& Min, W. 2010. Prevalence and cross immunity of Eimeria species on Korean chicken farms. Journal of Veterinary Medical Science 72(8): 985-989.

Lew, A.E., Anderson, G.R., Minchin, C.M., Jenston, P.J. \& Jorgensen, W.K. 2003. Inter- and intra-strain variation and PCR detection of the internal transcribed spacer 1 (ITS-1) sequences of Australian isolates of Eimeria species from chickens. Veterinary Parasitology 112: 33-50.

Lien, Y.Y., Sheu, S.C., Liu, H.J., Chen, S.C., Tsai, M.Y., Luo, S.C., Wu, K.C., Liu, S.S. \& Su, H.Y. 2007. Cloning and nucleotide sequencing of the second internal transcribed spacer of ribosomal DNA for three species of Eimeria from chickens in Taiwan. Veterinary Journal 173: 186-191.
Long, P.L. \& Joyner, L.P. 1984. Problems in identification of species of Eimeria. Journal of Protozoology 31: 535-541.

Long, P.L., Millard, B.J., Joyner, L.P. \& Norton, C.C. 1976. A guide to laboratory techniques used in the study and diagnosis of avian coccidiosis. Folia Veterinaria Latina 6: 201-217.

Morgan, J.A.T, Morris, G.M., Wlodek, B.M., Byrnes, R., Jenner, M., Constantinoiu, C.C, Anderson, G.R., Lew-Tabor, A.E., Molly, J.B., Gasser, R.B.\& Jorgensen, W.K. 2009. Real-time polymerase chain reaction (PCR) assays for the specific detection and quantification of seven Eimeria species that cause coccidiosis in chickens. Molecular and Cellular Probes 23: 83-89.

Notomi, T., Okayama, H., Masubuchi, H., Yonekawa, T., Watanabe, K., Amino, N. \& Hase, T. 2000. Loop-mediated isothermal amplification of DNA. Nucleic Acids Research 28(12): e63.

Poon, L.L., Wong, B.W., Ma, E.H., Chan, K.H., Chow, L.M., Abeyewikreme, W., Tangpukdee, N., Yuen, K.Y., Guan, Y., Looareesuwan, S. \& Peiris, J.S. 2006. Sensitive and inexpensive molecular test for falciparum malaria: Detecting Plasmodium falciparum DNA directly from heat-treated blood by loop-mediated isothermal amplification. Clinical Chemistry 52(2): 303-306.

Schnitzler, B.E., Thebo, P., Mattson, J.G., Tomley, F. \& Shirley, M.W. 1998. Development of a diagnostic PCR assay for the detection and discrimination of four pathogenic Eimeria species of the chicken. Avian Pathology 27: 490-497.

Schnitzler, B.E., Thebo, P., Mattson, J.G., Tomley, F., Uggla, A. \& Shirley, M.W. 1999. PCR identification of chicken Eimeria. Avian Pathology 27: 490-497.

Shirley, M.W. 1995. Eimeria species and strains of chickens. In Biotechnology - Guidelines on Techniques in Coccidiosis Research, edited by Eckert, J., Braun, R., Shirley, M.W. \& Coudert, P. Luxemborg: European Commision. pp. 1-24.

Shirley, M.W., Smith, A.L. \& Tomley, F.M. 2005. The biology of avian Eimeria with an emphasis on their control by vaccination. Advances in Parasitology 60: 285-330.

Sotiriadou, I. \& Karanis, P. 2008. Evaluation of loop-mediated isothermal amplification for detection of Toxoplasma gondii in water samples and comparative findings by polymerase chain reaction and immunoflourescence test (IFT). Diagnostic Microbiology and Infectious Disease 62(4): 357-365.

Stucki, U., Braun, R. \& Roditi, I. 1993. Eimeria tenella: Characterization of $5 \mathrm{~S}$ ribosomal RNA repeat subunit and its use as a species-specific probe. Experimental Parasitology 76: 68-75

Su, Y.C., Fei, A.C. \& Tsai, F.M. 2003. Differential diagnosis of five avian Eimeria species by polymerase chain reaction using primers derived from internal transcribed spacer 1 (ITS-1) sequence. Veterinary Parasitology 117: 221-227.

Sun, X.M., Pang, W., Jia, T., Yan, W.C., He, G., Hao, L.L., Bentue, M. \& Suo, X. 2009. Prevalence of Eimeria species in broilers with subclinical signs from fifty farms. Avian Disease 53: 301-305.

Tsuji, N., Kawazu, S., Ohta, M., Kamio, T., Isobe, T., Shimura, K. \& Fujisaki, K. 1997. Discrimination of eight chicken Eimeria species using the two-step polymerase chain reaction. Journal of Parasitology 83: 966-970.

Vrba, V., Blake, D.P. \& Poplstein, M. 2010. Quantitative realtime PCR assays for detection and quantification of all seven Eimeria species that infect the chicken. Veterinary Parasitology 174: 183-190. 
Williams, R.B., Bushell,A.C., Reperent, J.M., Doy, T.G., Morgan, J.H., Shirley, M.W., Yvore, P., Carr, M.M. \& Fremont, Y. 1996. A survey of Eimeria species in commercially-reared chickens in France during 1994. Avian Pathology 25: 113130 .

Shu-San Loo, Lik-Sin Lim, Nurul-Ain Efendi \& Kiew-Lian Wan* School of Biosciences and Biotechnology

Faculty of Science and Technology

Universiti Kebangsaan Malaysia

43600 UKM Bangi, Selangor Darul Ehsan

Malaysia

Shu-San Loo \& Kiew-Lian Wan*

Centre for Biotechnology and Functional Food

Faculty of Science and Technology

Universiti Kebangsaan Malaysia

43600 UKM Bangi, Selangor Darul Ehsan

Malaysia

Shu-San Loo

Agro-Biotechnology Institute

National Institutes of Biotechnology Malaysia

c/o MARDI Headquarters

43400 Serdang, Selangor Darul Ehsan

Malaysia
Lik-Sin Lim \& Kiew-Lian Wan*

Malaysia Genome Institute

National Institutes of Biotechnology Malaysia

Jalan Bangi, 43000 Kajang, Selangor Darul Ehsan

Malaysia

Damer P. Blake

The Royal Veterinary College

Hawkshead Lane, North Mymms

Hatfield, Hertfordshire

United Kingdom

Shin-ichiro Kawazu

National Research Center for Protozoan Diseases

Obihiro University of Agriculture and Veterinary Medicine

Obihiro, Hokkaido

Japan

*Corresponding author; email: klwan@ukm.edu.my

Received: 8 October 2018

Accepted: 30 April 2019 